\title{
Quality of Canned 'Ruddy' Kidney Beans as Influenced by Planting Date, Harvest Time, and Length of Storage before Canning
}

\author{
A.K. Forney ${ }^{1}$, D.E. Halseth ${ }^{2}$, and W.C. Kelly ${ }^{3}$ \\ Department of Vegetable Crops, Cornell University, Ithaca, NY 14853-0327 \\ Additional index words. Phaseolus vulgaris, dry beans, seed splitting, processing
}

\begin{abstract}
Four planting and harvest dates yielded 16 lots of 'Ruddy' red kidney beans (Phaseofus vulgaris L.) that were canned immediately after harvest in the fall and from storage in January and April. Late planting resulted in a high percentage of acceptable beans, but time of harvest had little effect on subsequent canning quality. The most important defect was transverse splitting from the hilum. Hilum splits, drained weight, cooked weight, and seed size were all negatively correlated with acceptability. Seed size was the most important factor determining quality, with the smallest seeds exhibiting the fewest splits. Length of storage had significant but small effects on canned seed quality.
\end{abstract}

There has been considerable interest in the quality of dry beans produced in New York state, particularly in relation to those factors that affect acceptability of the canned product. A major concern of processors is the high incidence of transverse cotyledon splits that originate in the hilum and/or micropyle region. Split beans detract from the appearance of the product and reduce quality by allowing deposition of starch material on the bottom of the can.

Investigations on the effect of processing method on splitting of canned kidney beans have been reported (Junek et al., 1980; Nordstrom and Sistrunk, 1977, 1979; Van Buren et al., 1986); however, minimal information is available on the effect of cultural or environmental conditions on canning quality. Faris and Smith (1964) noted that splitting in canned dark-red kidney beans varied "from year to year, from grower to grower, and even from one part of the field to another." Gonzalez et al. (1982) reported differences in drain weight, percent split beans, firmness, and seed color from season to season. Information on the effect of harvest moisture content on degree of seed splitting during canning varies widely in the literature. Faris and Smith (1964) found no correlation between seed moisture and splitting during canning, whereas Kays et al. (1980) found a positive correlation and Gonzalez et al. (1982) found a negative correlation.

Siddique and Goodwin (1980) reported that of 10 snap bean (Phaseolus vulgar-is L.) genotypes studied, all produced higherquality seed at low maturation temperatures. Plants were exposed to their designated temperature regimes when seeds were at their maximum fresh weight. Seeds that matured at day temperatures above $21 \mathrm{C}$ were of poor quality, as measured by seedling evaluation, and were more susceptible to mechanical damage.

The objective of this study was to investigate the effects of planting date and harvest date on seed weight, yield, and canning quality of light-red kidney beans. The effect of storage time before canning was also evaluated.

\section{Materials and Methods}

'Ruddy' light-red kidney beans were grown at the Homer C. Thompson Vegetable Research Farm, Freeville, N. Y., on a

Received for publication 7 Dec. 1989. The cost of publishing this paper was defrayed in part by the payment of page charges. Under postal regulations, this paper therefore must be hereby marked advertisement solely to indicate this fact. 'Graduate Student.

${ }^{2}$ Assistant Professor.

${ }^{3}$ Professor Emeritus.
Howard gravelly loam soil (loamy-skeletal, mixed mesic, Glossoboric Hapludalf). Standard cultural practices were followed in growing the dry beans, i.e., fertilizer was applied in bands at planting $\left(334 \mathrm{~kg} \cdot \mathrm{ha}^{-1}\right.$ of 7 . $0 \mathrm{~N}-9.2 \mathrm{P}-11.6 \mathrm{~K}-1.2 \mathrm{Mg}-0.2 \mathrm{~B}-$ $0.15 \mathrm{Mn}$ ); row width was $76 \mathrm{~cm}$, seed spacing $5.9 \mathrm{~cm}$ within the row, and no irrigation was used. The planting dates and harvest days after planting (DAP) were 26 May 1986 (92, 98, 108, and 120 DAP); 4 June (94, 99, 111, and 130 DAP); 14 June (93, 101, 120, and 131 DAP); and 23 June (111, 122, 131, and 137 DAP). The experimental design was a split-splitplot with planting dates as main plots, harvest dates as subplots, and length of storage as sub-subplots. There were four replications of the main plots, each of which was $30.5 \mathrm{~m}$ long by 4 rows wide. Each main plot was divided into four 7.6-m subplots. The center $(6.1 \mathrm{~m})$ of the inner two rows of each subplot (=195 plants) was harvested.

Plant growth stage was recorded weekly, and climatological data were collected at a weather station near the research plots. Beans were hand-harvested, shelled using a rubber belt thresher, cleaned over velvet rolls, and finally hand-selected. Swollen, high-moisture beans were discarded to simulate commercial seed cleaning. Remaining samples were weighed and moisture content determined with a Burrows Model 700 digital moisture computer (Seedburo Equipment Co., Chicago). Seed weight was also determined. Yield and seed weight were calculated on the basis of $18 \%$ seed moisture.

A 400-g sample of the beans from each planting-harvest subplot was canned shortly after harvest. The remaining beans from each subplot were air-dried to $=17 \%$ moisture, put in polyethylene bags, and stored at 7C. A second sample from each subplot was canned on 22 Jan. and a third on 23 Apr.

Beans were weighed and moisture content (canning moisture) determined before processing. The beans were then soaked overnight at $21 \mathrm{C}$ in four volumes of distilled water, drained, blotted dry with cheesecloth, and reweighed. Soak weight was calculated as grams of water taken up per gram of dry matter. The soaked beans ( $200 \mathrm{~g},=200$ seeds) were placed in a \#303 (8 $\mathrm{cm}$ in diameter $\times 11 \mathrm{~cm}$ tall) can that was filled with brine consisting of $350 \mathrm{ppm} \mathrm{CaCl}_{2}, 250 \mathrm{ppm} \mathrm{Na} \mathrm{NaDTA}_{2}$, and $2 \%$ $\mathrm{NaCl}$ in distilled water. The cans were then passed through an exhaust tunnel to raise the can contents to $66 \mathrm{C}$, immediately closed, processed in a still retort at $118 \mathrm{C}$ for 30 rein, and watercooled. Two cans were processed from each plot at each canning time for a total of 384 cans.

Following storage at 20C for 9 weeks, drained weight was 
determined by draining the can contents on a \#8 sieve for 3 min and then weighing. Drained weights were expressed as grams of weight gain per gram of dry matter. Cooked weight was measured as the amount of weight gain during cooking and was expressed as grams of weight gain per gram of dry matter.

Every bean from each can was subjectively classified into one of four categories according to the type and severity of seed damage. 1) Acceptable: beans had no breakage or had splits $<2$ mm long. 2) Hilum: beans with any splits across the hilum or micropyle region proceeding transversely on both sides of the bean. Hilum splits are generally considered most undesirable by processors since they often result in broken beans. 3) Longitudinal breakage: beans with splits $>2 \mathrm{~mm}$ long that did not originate in the hilum or micropyle area. 4) Hilum-longitudinal: beans with splits that crossed the hilum or micropyle area but curved toward the long axis of the seed and were usually on only one side. The number and weight of the beans in each category were determined. Values reported are percentages based on the total number of beans in each can.

To investigate the effect of seed size on canning quality, beans were harvested on 12 Nov. from the 4 June planting. These samples ( $5 \mathrm{~kg}$ from each of four replications) were threshed and cleaned as described above, but were allowed to dry (held on screen racks at $21 \mathrm{C}$ for $=2$ weeks) to a $10 \%$ moisture content, held in storage at $7 \mathrm{C}$ until 12 Feb., then sized and canned. Beans were sized using a set of nesting bean sieves having slots $19.1 \mathrm{~mm}$ long, widths from 5.16 to $6.75 \mathrm{~mm}$ (in steps of 0.40 $\mathrm{mm})$. Canning and evaluation procedures were as described above.

Data analyses were performed on an IBM 3090 computer using the SAS statistical program (SAS Institute, 1985). WallerDuncan's multiple comparison procedure was used to determine significant differences among treatments. To study the relationship of various traits, simple $\left(r^{-}\right)$and multiple $\left(\mathrm{R}^{*}\right)$ correlations were calculated using data from the cans evaluated $(n=384$ for planting date $\mathbf{x}$ harvest date experiment and $n=32$ for seed size study).

\section{Result: and Discussion}

Seed moisture content at harvest was significantly different for both planting and harvest dates, and there was a significant planting date $\mathbf{x}$ harvest date interaction (Table 1). The initial harvest for each planting date occurred when $85 \%$ to $90 \%$ of

Table 1. Effect of planting date and harvest time on moisture at harvest, yield, and seed weight of light-red kidney beans.

\begin{tabular}{lccc}
\hline \hline Variable & $\begin{array}{c}\text { Harvest } \\
\text { moisture } \\
(\%)\end{array}$ & $\begin{array}{c}\text { Yield } \\
\left(\mathrm{kg}^{\circ} \mathrm{ha}^{-1}\right)\end{array}$ & $\begin{array}{c}\text { Seed wt } \\
(\mathrm{g} / 100 \text { seed })\end{array}$ \\
\hline $\begin{array}{l}\text { Planting date } \\
\text { 27 May } \\
\text { 4 June }\end{array}$ & $22.7 \mathrm{C} \%$ & $2782 \mathrm{bc}$ & $52.0 \mathrm{~b}$ \\
14 June & $22.4 \mathrm{C}$ & $3096 \mathrm{a}$ & $54.1 \mathrm{a}$ \\
23 June & $23.9 \mathrm{~b}$ & $2937 \mathrm{ab}$ & $52.6 \mathrm{~b}$ \\
Harvest & $24.9 \mathrm{a}$ & $2724 \mathrm{C}$ & $48.6 \mathrm{C}$ \\
1 & & & \\
2 & $23.9 \mathrm{~b}$ & $2610 \mathrm{~b}$ & 52.1 \\
3 & $22.5 \mathrm{C}$ & $2973 \mathrm{a}$ & 51.4 \\
4 & $21.5 \mathrm{~d}$ & $3004 \mathrm{a}$ & 51.6 \\
Interaction & $26.1 \mathrm{a}$ & $2951 \mathrm{a}$ & 52.1 \\
Planting x harvest & $* *$ & $* *$ & NS \\
\hline
\end{tabular}

${ }^{2}$ Mean separation within main effect means by Wailer-Duncan k-ratio $t$ test, $P=0.05$.

NS, **Nonsignificant or significant at $P=0.01$, respectively. the pods were dry (pods were light-tan in color and papery in texture). Sampling continued for the second and third harvest dates when $=93 \%$ and $97 \%$, respectively, of the pods in each subplot were dry and was completed with the fourth harvest, when all pods were dry. These harvest criteria resulted in 11 harvest dates, ranging from 26 Aug. through 7 Nov. Five of these harvest dates were shared by two or three planting dates, and all but the first and last two harvest dates overlapped for the four planting dates. Harvest moisture of seed ranged from $18 \%$ to $30 \%$, caused by sporadic rainfall that dehydrated some bean samples before harvest. The staggering of the four harvest dates for each of the four planting dates resulted in obtaining subsequent samples that were not always on the decline for moisture content; hence, the significant planting $\mathrm{x}$ harvest date interactions for seed moisture.

In this study, harvest moisture was not an important factor in the occurrence of splits caused by handling, since the beans were pulled by hand and threshed with a belt thresher that minimized mechanical damage. However, with current commercial harvesting techniques, seed moisture is very important because high moisture content reduces the susceptibility of beans to mechanical damage (Associated Seed Growers, 1949). Barriga (1961) and Dexter (1966) also noted the importance of bean moisture content in relation to susceptibility to mechanical damage, as measured by checked skins, cracked seeds, germination, and seedling vigor. Smith and Faris (1963) found a positive correlation between mechanical damage and the splitting of dark-red kidney beans when canned.

Yield varied considerably over the planting dates. The 4 June planting had a higher yield than did the 27 May or 23 June plantings (Table 1). Time of harvest did not affect yield, except that the first harvests had a significantly lower yield, as would be expected since bloated, high-moisture beans were discarded before moisture and yield determinations (Table 1). There was a significant interaction between planting dates and harvest dates for yield, primarily due to an extremely low yield in one replication (low, wet area in field) for the last two harvests of the 23 June planting (data not shown).

Weight of dry seeds before canning was highest for the second planting and lowest for the fourth planting. The weights for the other two plantings were intermediate and similar (Table 1). The last planting, at $50 \%$, had by far the highest percentage of acceptable beans (Table 2); there were no differences in seed weight attributable to harvest time.

The 27 May and 4 June plantings experienced the highest temperatures (above 21C) during bean maturation. The lowest maturation temperature was for the 23 June planting, which also had the fewest split beans. There was a decrease in mean temperature as plantings were delayed, but no dramatic environmental change that would explain the striking increase in acceptability with the last planting. Planting late reduced yield and seed size yet greatly improved acceptability. The yield reduction was due to the low weight per seed, since the ratio of seed weight to yield was almost identical for all of the plantings. Scarisbrick et al. (1976) reported this infelicitous correlation between seed size and yield.

Time of harvest had less effect than did time of planting on the percentage of acceptable beans, although the fourth harvest had a higher percentage of acceptable beans than did the other three harvests (Table 2). Past studies showed no agreement on the effect of harvest time on bean quality (Faris and Smith, 1964; Gonzalez et al., 1982; Kays et al., 1980). In our study, late harvest resulted in improved acceptability of the canned 
Table 2. Effect of planting date, time of harvest, and length of storage on the percentage of acceptable beans and on the percentage of beans with various types of splits in canned light-red kidney beans.

\begin{tabular}{lclll}
\hline \hline & & \multicolumn{3}{c}{ Type of split (\%) } \\
\cline { 3 - 5 } Variable & $\begin{array}{c}\text { Acceptable } \\
(\%)\end{array}$ & Hilum & $\begin{array}{c}\text { Hilum- } \\
\text { longitudinal }\end{array}$ & Longitudinal \\
\hline Planting date & & & & \\
27 May & $11.2 \mathrm{c}^{\mathrm{z}}$ & $59.1 \mathrm{ab}$ & 22.6 & $7.1 \mathrm{a}$ \\
4 June & $14.0 \mathrm{c}$ & $62.4 \mathrm{a}$ & 20.1 & $3.4 \mathrm{c}$ \\
14 June & $21.8 \mathrm{~b}$ & $54.9 \mathrm{~b}$ & 18.9 & $4.5 \mathrm{bc}$ \\
23 June" & $50.0 \mathrm{a}$ & $24.8 \mathrm{c}$ & 19.5 & $5.7 \mathrm{~b}$ \\
Harvest & & & & \\
1 & $21.8 \mathrm{~b}$ & $53.0 \mathrm{a}$ & 19.9 & 5.3 \\
2 & $23.5 \mathrm{~b}$ & $50.9 \mathrm{ab}$ & 20.8 & 4.9 \\
3 & $24.2 \mathrm{~b}$ & $50.0 \mathrm{ab}$ & 20.4 & 5.4 \\
4 & $27.5 \mathrm{a}$ & $47.3 \mathrm{~b}$ & 20.1 & 5.2 \\
Storage & & & \\
0 & $21.9 \mathrm{~b}$ & $48.0 \mathrm{~b}$ & $24.7 \mathrm{a}$ & $5.4 \mathrm{~b}$ \\
3 & $24.9 \mathrm{a}$ & $48.4 \mathrm{~b}$ & $20.5 \mathrm{~b}$ & $6.1 \mathrm{a}$ \\
6 & $25.9 \mathrm{a}$ & $54.5 \mathrm{a}$ & $15.6 \mathrm{C}$ & $4.0 \mathrm{c}$ \\
\hline
\end{tabular}

${ }^{7}$ Mean separation within main effect means by Wailer-Duncan k-ratio t test, $P=0.05$.

Table 3. Effect of planting date, time of harvest, and length of storage on canning moisture and on the soak, drained, and cooked weights of light-red kidney beans.

\begin{tabular}{|c|c|c|c|c|}
\hline Variable & $\begin{array}{c}\text { Canning } \\
\text { moisture } \\
(\%)\end{array}$ & Soak wt & Drained wt & Cooked wt \\
\hline \multicolumn{2}{|c|}{ Planting date } & \multicolumn{3}{|c|}{ (grams/gram dry matter) } \\
\hline 27 May & $18.47 \mathrm{~b}^{\mathrm{z}}$ & 1.327 & $2.093 \mathrm{a}$ & $0.767 \mathrm{a}$ \\
\hline 4 June & $18.83 \mathrm{~b}$ & 1.325 & $2.054 \mathrm{~b}$ & $0.729 \mathrm{~b}$ \\
\hline 14 June & $18.99 \mathrm{~b}$ & 1.329 & $2.027 \mathrm{C}$ & $0.698 \mathrm{C}$ \\
\hline 23 June & $19.63 \mathrm{a}$ & 1.319 & $1.952 \mathrm{~d}$ & $0.633 \mathrm{~d}$ \\
\hline \multicolumn{5}{|l|}{ Harvest } \\
\hline 1 & $18.57 \mathrm{~b}$ & $1.335 \mathrm{a}$ & $2.054 \mathrm{a}$ & $0.719 \mathrm{a}$ \\
\hline 2 & $18.66 \mathrm{~b}$ & $1.331 \mathrm{ab}$ & $2.031 \mathrm{~b}$ & $0.700 \mathrm{~b}$ \\
\hline 3 & $18.62 \mathrm{~b}$ & $1.325 \mathrm{~b}$ & $2.045 \mathrm{a}$ & $0.720 \mathrm{a}$ \\
\hline 4 & $20.07 \mathrm{a}$ & $1.307 \mathrm{c}$ & $1.996 \mathrm{C}$ & $0.688 \mathrm{~b}$ \\
\hline \multicolumn{5}{|c|}{ Storage (months) } \\
\hline 0 & $23.48 \mathrm{a}$ & $1.361 \mathrm{a}$ & $2.123 \mathrm{a}$ & $0.761 \mathrm{a}$ \\
\hline 3 & $16.73 \mathrm{~b}$ & $1.303 \mathrm{c}$ & $1.984 \mathrm{~b}$ & $0.682 \mathrm{~b}$ \\
\hline 6 & $16.73 \mathrm{~b}$ & $1.311 \mathrm{~b}$ & $1.987 \mathrm{~b}$ & $0.677 \mathrm{~b}$ \\
\hline
\end{tabular}

'Mean separation within main effect means by Wailer-Duncan k-ratio t test, $P=0.05$.

product. However, this improvement would not warrant the risk of late harvest in humid regions, such as the northeastern United States. This is especially true if 'Ruddy' is grown for dry pack, since it loses its bright pink appearance with exposure to fall wetting and drying cycles (R.F. Sandsted, personal communication).

Beans canned soon after harvest had a lower percentage of acceptable beans than did those canned after storage (Table 2). There were no differences between those stored for 3 or 6 months. Planting dates, harvests, and storage periods all resulted in significant differences in types of splitting (Table 2) and water uptake during canning (Table 3). After canning, the average weight per seed of good beans was $1.04 \mathrm{~g}$, while beans with moderate hilum splits averaged $1.17 \mathrm{~g}$, and those with extremely severe hilum splits averaged $1.33 \mathrm{~g} / \mathrm{seed}$. There was good consistency in weight per bean for each damage category over all three storage and evaluation periods (data not shown).

The relationship between weight gain during retorting (cooked weight) and severity of splitting is supported by the results of
Sastry et al. (1985), who found that moisture content after retorting for various processes was significantly different, whereas moisture content after soak was not different. Beans with severe splits weighed more, possibly due to greater uptake of water, than their unsplit or less split counterparts. These observations are consistent with those of Sastry et al. (1985), who found that beans with higher moisture content after retorting had more splits.

To simplify the complex relationships between the quality of canned beans, their water uptake during the various stages of processing, and the types of, seed damage, linear correlations were calculated for all of the variables (Table 4). Cooked, drained, and seed weights and hilum splits had a significant negative correlation with the percentage of acceptable beans (Table 4A). Hilum-longitudinal and longitudinal splits, as well as soak weight, had little relation to acceptability. Drained weight was positively correlated with cooked, soak, and seed weights. Multiple linear correlation procedures showed that cooked-weight and seed weights accounted for $76 \%\left(R^{2}=0.76\right)$ of the variance associated with acceptability. By including canning moisture, drained weight, harvest moisture, and yield in the above model, $83 \%$ $\left(R^{2}=0.83\right)$ of the variance was accounted for. Drained weight added a minimal variance, since cooked weight was already included and they were highly correlated. Multiple linear correlation of factors that could be determined before canning (seed weight, soak weight, harvest moisture, canning moisture, and yield) accounted for only $59 \%\left(R^{2}=0.59\right)$ of the variance.

The beans that were sized mechanically before canning exhibited the predominant effect of seed weight on splitting and acceptability (Tables 4B and 5). The correlation coefficients for seed weight and type of splitting were higher with the sized beans than with the whole population. Drained weight and cooked weight were not significantly correlated with seed size with the sized beans, but the number of observations was much lower than for the whole experiment. Seed weight alone accounted for $81 \%\left(R^{2}=0.81\right)$ of the variance and adding drained weight increased the variance to $91 \%\left(R^{2}=0.91\right)$.

The sized beans were harvested later than the main experiment but exhibited similar correlations between measured variables, as was found for the last harvest of the second planting. The different seed sizes were not equally distributed by seed count in the field samples, $=11 \%$ for both the largest and smallest beans and $75 \%$ in the two intermediate sizes combined. Planting date affected the weight of the seed (Table 1); however, beans of the same size grown under different environments may not have the same canning quality. This lack of a relationship was evident, since the first planting was least acceptable even though seed weight was not the highest.

The negative correlation of seed weight and percent acceptable beans probably applies only within a cultivar, as some cultivars that have much larger average seed size also produce a higher percentage of acceptable beans than 'Ruddy' (D. E. H., unpublished data). Faris and Smith (1964) stated that small seed would be expected to exhibit reduced splitting because of the larger surface area : volume ratio. In addition to their reduced propensity to split, small seed also have a greater tolerance to mechanical damage (Dorrell and Adams, 1969), presumably due to smaller impact forces. Clark and Peck (1968) reported that small snap bean seeds generally have a higher germination percentage and more seedlings with intact cotyledons than do larger seeds. Seed weight was positively correlated with yield $(r=0.42)$.

The ability to predict processing quality of beans before canning is desirable. Unfortunately, factors that could be measured 
Table 4. Linear correlations ( $\mathrm{r}$ ) of percentage acceptable beans with other measured variables of canned kidney beans. (A) Beans canned from four plantings and four harvest times $(n=384)$ and $(B)$ beans canned from one planting and harvest time, mechanically separated into four seed sizes $(\mathrm{n}=32)$.

\begin{tabular}{|c|c|c|c|c|c|c|c|}
\hline \multirow[b]{2}{*}{$\begin{array}{l}\text { Seed } \\
\text { variables }\end{array}$} & \multirow[b]{2}{*}{ Acceptable } & \multicolumn{3}{|c|}{ Type of split } & \multirow[b]{2}{*}{$\begin{array}{l}\text { Soak } \\
1 \mathrm{wt} \\
\end{array}$} & \multirow[b]{2}{*}{$\begin{array}{c}\text { Drained } \\
\text { Wt }\end{array}$} & \multirow[b]{2}{*}{$\begin{array}{c}\text { Cooked } \\
\text { Wt }\end{array}$} \\
\hline & & Hilum & $\begin{array}{l}\text { Hilum- } \\
\text { longitudinal }\end{array}$ & Longitudinal & & & \\
\hline \multicolumn{8}{|l|}{ A } \\
\hline Hilum & $-0.90^{* *}$ & & & & & & \\
\hline Hilum-long & $-0.15^{*}$ & $-0.29 * *$ & & & & & \\
\hline Longitudinal & -0.06 & $-0.20 * *$ & $0.29^{* *}$ & & & & \\
\hline Soak weight & -0.13 & 0.01 & $0.33^{* *}$ & -0.11 & & & \\
\hline Drained weight & $-0.66^{* *}$ & $0.50^{* *}$ & $0.32 * *$ & 0.13 & $0.61^{* *}$ & & \\
\hline Cooked weight & $-0.75^{* *}$ & $0.59 * *$ & $0.24^{* *}$ & $0.21^{* *}$ & $0.31^{* *}$ & $0.94 * *$ & \\
\hline Seed weight & $-0.72^{* *}$ & $0.77^{* *}$ & $-0.15^{* *}$ & -0.09 & 0.00 & $0.34^{* *}$ & $0.41 * *$ \\
\hline \multicolumn{8}{|l|}{ B } \\
\hline Hilum & $-0.95^{* *}$ & & & & & & \\
\hline Hilum-long & 0.20 & -0.47 & & & & & - \\
\hline Longitudinal & $-0.78^{* *}$ & $0.73^{* *}$ & -0.29 & & & & \\
\hline Soak weight & -0.27 & 0.07 & 0.47 & 0.34 & & & \\
\hline Drained weight & $-0.63^{* *}$ & 0.44 & 0.37 & $0.51^{*}$ & $0.55^{*}$ & & \\
\hline Cooked weight & $-0.53^{*}$ & 0.46 & 0.06 & 0.34 & -0.14 & $0.75^{* *}$ & \\
\hline Seed weight & $-0.90^{* *}$ & $0.95^{* *}$ & $-0.54^{*}$ & $0.83 * *$ & 0.13 & 0.37 & 0.34 \\
\hline
\end{tabular}

Table 5. Effect of seed size on seed weight, percentage of acceptable beans, and the percentage of beans with various types of splits in light-red kidney beans.

\begin{tabular}{|c|c|c|c|c|c|}
\hline \multirow{2}{*}{$\begin{array}{c}\text { Size } \\
(\mathrm{mm}) \\
\end{array}$} & \multirow{3}{*}{$\begin{array}{c}\text { Seed } \\
\text { wt } \\
(\mathrm{g} / 100 \text { seed })\end{array}$} & \multirow{3}{*}{$\begin{array}{c}\text { Acceptable } \\
(\%)\end{array}$} & \multicolumn{3}{|c|}{ Type of split (\%) } \\
\hline & & & & Hilum- & \\
\hline On-thru ${ }^{z}$ & & & Hilum & longitudi & I \\
\hline .56 & & & 21.1 & & \\
\hline & & & & & \\
\hline & 58.4 & & 50.2 & 22 . & $8.0 \mathrm{a}$ \\
\hline $6.35-6.75$ & $64.6 \mathrm{a}$ & $14.6 \mathrm{c}$ & $60.5 \mathrm{a}$ & $16.8 \mathrm{~b}$ & $8.1 \mathrm{a}$ \\
\hline
\end{tabular}

${ }^{2}$ Beans were sized on a set of nesting sieves having slots $19.1 \mathrm{~mm}$ long with widths from 5.16 to $6.75 \mathrm{~mm}$ (in steps of $0.40 \mathrm{~mm}$ ). Seeds were classified into a size category when seed rested "on" the narrower slot but fell "thru" the wider slot. Inch equivalents for the smallest were $13 / 64-14 / 64$, for the largest 16/64-17/64.

${ }^{y}$ Mean separation within columns by Wailer-Duncan k-ratio $t$ test, $P$ $=0.05$.

before cooking accounted for only 59\% $\left(R^{2}=0.59\right)$ of the variance in this study. Once canned, a processor could employ a visual rating system to determine the acceptability of a particular lot. In the seed size study, seed weight alone accounted for $81 \%\left(R^{2}=0.81\right)$ of the variance associated with acceptability. However, these beans were from one planting and one harvest date, while the other beans involved a wide range of planting and harvest times.

Identifying the significant physiological and environmental factors affecting splitting of canned kidney beans could assist plant breeders, growers, and processors in producing a consistently improved product. Plant breeders could use this information to develop screening tools to select for damage-resistant bean lines. Growers might be able to modify or improve the timeliness of their cultural practices to minimize the impact of the environment on bean quality. Processors might benefit by implementing modified processing techniques, such as chemical additives to brine solutions, to minimize breakage. However, the tendency for beans to split is only one aspect of quality in the processed product. Uniformity of size, color, flavor, and texture are also important variables that must be evaluated in the final product when new dry bean cultivars or processing procedures are developed.

\section{Literature Cited}

Associated Seed Growers, Inc. 1949. A study of mechanical injury to seed beans. Asgrow Monogr. 1:1-45.

Barriga, C. 1961. Effects of mechanical abuse of navy bean seed at various moisture levels. Agron. J. 53:250-251.

Clark, B.E. and N.H. Peck. 1968. Size and performance of snap bean seeds. New York's Food \& Life Sci. Quarterly 1(1):17-19.

Dexter, S.T. 1966. Conditioning dry bean seed (Phaseolus vulgaris L.) for better processing quality and seed germination. Agron. J. 58:629-631.

Dorrell, D.G. and M.W. Adams. 1969. Effect of some seed characteristics on mechanically induced seedcoat damage in navy beans (Phaseolus vulgaris L.). Agron. J. 61:672-673.

Faris, D.G. and F.L. Smith. 1964. Effect of maturity at time of cutting on quality of dark red kidney beans. Crop Sci. 4:66-69.

Gonzalez, A. R., K.M. Edwards, and D.B. Marx. 1982. Storage and processing quality of beans (Phaseolus vulgaris L.) harvested at the semi-dry stage. J. Amer. See. Hort. Sci. 107:82-86.

Junek, J. J., W.A. Sistrunk, and M.B. Neely. 1980. Influencc of processing methodology on quality attributes of canned dry beans. J. Food Sci. 45:821-824.

Kays, S.J., J.W. Williams, and D.R. Davis. 1980. Harvest of dry beans in the pre-dry stage of development: Effect on yield and processed product quality. J. Amer. Soc. Hort. Sci. 105:15-17.

Nordstrom, C.L. and W.A. Sistrunk. 1977. Effect of type of bean, soak time, canning media and storage time on quality attribute and nutritional value of canned dry beans. J. Food Sci. 42:795-798.

Nordstrom, C.L. and W.A. Sistrunk. 1979. Effect of type of bean, moisture level, blanch treatment and storage time on quality attributes and nutrient content of canned dry beans. J. Fond Sci. 44:392-395.

SAS Institute, Inc. 1985. SAS user's guide: Statistics. 5th ed. SAS Inst., Cary, N.C.

Sastry, S.K., F.D. McCafferty, E.G. Murakami, and G.D. Kuhn. 1985. A research note: Effects of vacuum hydration on the incidence of splits in canned kidney beans (Phaseolus vulgaris). J. Food Sci. 50:1501-1502.

Scarisbrick, D. H., M.K.V. Carr, and J.M. Wilkes. 1976. The effect of sowing date and season on the development and yield of navy beans (Phaseolus vulgaris) in southeast England. J. Agr. Sci. 86:65-76.

Siddique, M.A. and P.B. Goodwin. 1980. Maturation temperature influences $\mathrm{cm}$ seed quality and resistance to mechanical injury of some snap bean genotypes. J. Amer. Soc. Hort. Sci. 105:235-238

Smith, F.L. and D.G. Faris. 1963. Cutting dates affect cooking quality of dark red kidney beana. Calif. Agr. 17:14-16.

Van Buren, J., M. Bourne, D. Downing, D. Queale, E. Chase, and S. Comstock. 1986. Processing factors influencing splitting and other quality characteristics of canned kidney beans. J. Food Sci. 51:1228-1230. 